\title{
Sognepræst i Daler Andreas Wedels strid med sin menighed om konfirmation og gebyrer 1707-09
}

\section{Af Peter Kr. Iversen}

Ved et uheld er nærværende artikel om Daler-præsten Andreas Wedel og hans konflikter med sine sognebørn blevet skrevet. Jeg havde overset eller måske rettere sagt glemt, at $G$. N. Rühmann, Wedels langt senere efterfølger i embedet som sognepræst i Daler, i Sønderjyske Årbøger 1933 under titlen: "Fra pietismens første tid. Hvorledes det gik med et forsøg på før tiden at indføre konfirmationen « har benyttet til dels, men også kun til dels, det samme kildemateriale som jeg ved fremstillingen af samme begivenhedsforløb. Rühmanns syn på den stridbare præst, som har så svært ved at vende den anden kind til, er nok så positivt som mit. Da det ikke kan være helt uinteressant at se, hvad to historiske forfattere uafhængigt af hinanden kan få ud af samme materiale, og da vel kun de ganske få har Rühmanns artikel fra 1933 $i$ erindringen eller p̊̊ boghylden, har jeg ment, at det kan forsvares, at min fremstilling af begivenhederne i Daler i første årti af 1700-tallet publiceres.

Da sognepræsten i Daler Ægidius Hansen Gram var blevet gammel og svag og ikke selv kunne passe sit embede tilfredsstillende, indgik han i marts 1705 en afståelses- og præsteenkepensionskontrakt med den daværende teologiske student Andreas Egidiussen Wedel, som var præstesøn fra Brøns. ${ }^{1}$ Ved denne kontrakt bestemtes, at Ægidius Hansen Gram, så længe han levede, skulle forblive hovedpræst i Daler, medens Andreas Wedel blev hans medhjælper og fik løfte på at efterfølge ham i embedet. Samtidig bestemtes, at Andreas Wedel skulle indgå ægteskab med Grams datter Anna Cathrina. I kontrakten, som er gengivet i sin helhed i Sønderjyske Årbøger 1937, redegøres nøje for, hvorledes der skulle forholdes både før og efter det unge pars bryllup, og hvordan enken skulle forsørges ved Grams død. Andreas Wedel tiltrådte altså stillingen som medhjælper foråret 1705 og blev også gift med Anna Catharina, som imidlertid efter en fødsel allerede døde den 13. november $1707 \mathrm{i}$ en alder af kun 24 år. $^{2}$ Svigerfaderen var død 
nogle måneder $\mathrm{i}$ forvejen, og den unge præst stod da ved udgangen af 1707 som sognepræst og enkemand med store forpligtigelser over for svigermoderen. Med hende og hendes børn kom han næsten straks $i$ konflikt om overholdelsen af afståelses- og enkepensionskontrakten af 1705. Hun, som i hvert fald senere navnlig støttedes af svigersønnen, rådmand $\mathrm{i}$ Tønder Peter Giese, viste allerede $\mathrm{i}$ nådsensåret, at hun var en dame, der vidste, hvad hun kunne tilkomme, og som pressede Andreas Wedel til at overholde sine kontraktlige forpligtigelser, hvor vanskeligt det end kunne være for ham at inddrive pengene dertil i det lille, beskedne præstekald, Daler sogn var.

Dette må haves $\mathrm{i}$ erindringen, når man ser på den unge præsts højst forunderlige optræden over for sin menighed i årene 1707-09. Han, der var tipoldebarn af Anders Sørensen Wedel, siges lige som denne at have haft temperament, og han kunne jo heller ikke være upåvirket af sin unge hustrus alt for tidlige død. ${ }^{3}$

\section{Konfirmation i Daler 1707}

Andreas Wedel var som sagt præstesøn fra Brøns, hvor han var født 1677. Han gik på latinskole i Ribe, hvorfra han blev student 1695, hvilket år han blev immatrikuleret ved Københavns Universitet. Allerede på et tidligt tidspunkt må han være blevet påvirket $i$ pietistisk retning, idet han, så snart han havde tiltrådt stillingen i Daler, sammen med sin svagelige svigerfader må være begyndt på at indføre reformer. Det ses af, at sidstnæunte allerede den 19. marts 1705 efter klage fra menigheden fik en påmindelse fra det grevelige schackenborgske herskab om, at han skulle overholde de gejstlige ritualer og kirkelige ceremonier bedre end hidtil - såvel med hensyn til salmesang som brugen af kirkelys ved bondebryllupper. Det nævnes ikke, men præst og svigersøn har nok ladet sig tilflyde nogle ekstra accidenser, og da Egidius Hansen Gram var den ansvarlige sognepræst, var det ham, der fik den grevelige "næse ${ }^{3 a)}$

Andreas Wedel skulle dog snart selv komme i ilden, og det skete straks efter svigerfaderens død den 26. februar 1707. Det blev hans forsøg på at indføre konfirmationen $\mathrm{i}$ det kongerigske Daler sogn, som blev en af anledningerne til det voldsomme opgør mellem ham og menighed, der fandt sted $\mathrm{i}$ de følgende år. Selv siger han om sit forsøg ${ }^{4}$ på at indføre konfirmationen i Daler sogn, at han ved sit embedes tiltrædelse fornam, at en del af forældrene ikke havde villet lade deres 
børn gå så længe i skole, at de kunne lære deres katekismus og dens forklaring. Så snart børnene havde lært nogenlunde at læse, var de blevet taget ud af skolen - pigerne for at kniple og drengene for at gå til søs eller komme ud at tjene. Når børnene derefter var så gamle, at de forste gang skulle til alters, kom forældrene en fredag med dem til overhøring, for at de den følgende søndag kunne komme til Herrens bord. Ved fredagsoverhøringen viste det sig ifølge præsten, at mange ikke kunne deres katekismus ordret og ej heller forstod den, fordi de sjældent lod sig se ved den sædvanlige ungdomsundervisning. Andreas Wedel havde derfor adskillige gange besværet sig til forældrene herover og havde formanet dem til at sende de børn i skole, som med det første agtede sig til alters og også at lade dem komme $\mathrm{i}$ kirke, når der dér undervistes i den kristne børnelærdom. Der var da sket det, at nogle af forældrene, som Andreas Wedel kalder de velsindede, var kommet til ham og havde bedt ham fremskaffe en trykt katekismus, hvis forklaring var forståelig for børnene. Hans svigerfader, den tidligere præst, havde benyttet et håndskrevet hæfte, men mange af børnene, især pigerne, havde ikke lært så meget i skolen, at de kunne læse håndskriften. Han havde derfor overvejet, hvorledes denne utrykte katekismus kunne blive trykt, men alt imens var der kommet en bogfører fra Flensborg, som i sin kollektion havde en brugbar katekismus. Det var arkidiakon i Haderslev Paul Sass' danske oversættelse af den kongelige generalsuperintendent Christian von Stöckens tyskskrevne katekismus. Andreas Wedel havde fundet denne katekismus så let læselig og nyttig, at han havde anbefalet den til forældrene, og en del af disse havde da også købt den til deres børn. I øvrigt brugtes denne katekismus i de slesvigske nabosogne til menighedernes fulde tilfredshed.

Fra at bruge denne katekismus og til at indføre den form for konfirmation, som anvendtes i de slesvigske nabosogne, var der ikke langt. Han havde drøftet denne sag med enkegrevinde Sophia Dorothea Schack, født Marschalck, den 25. juli 1706 efter en gudstjeneste i Møgeltønder kirke, hvor han havde prædiket den dag. Han havde da bl.a. refereret over for grevinden, som i sønnens fravær i udlandet var Daler kirkes fungerende patron, at forældrene nødigt ville lade deres børn gå $\mathrm{i}$ skole for at blive undervist $\mathrm{i}$ katekismen så længe, indtil de første gang skulle til alters. Grevinden havde da sagt til ham, at han skulle bære sig ad ligesom præsterne i Haderslev provsti og i øvrigt alle vegne deromkring $\mathrm{i}$ hertugdømmet, »hvor der - både til at opmuntre forældrene til des flittigere at sende deres børn til skole og børnene des mere at beflitte sig på at lære deres Guds kundskab - holdes offentlig 


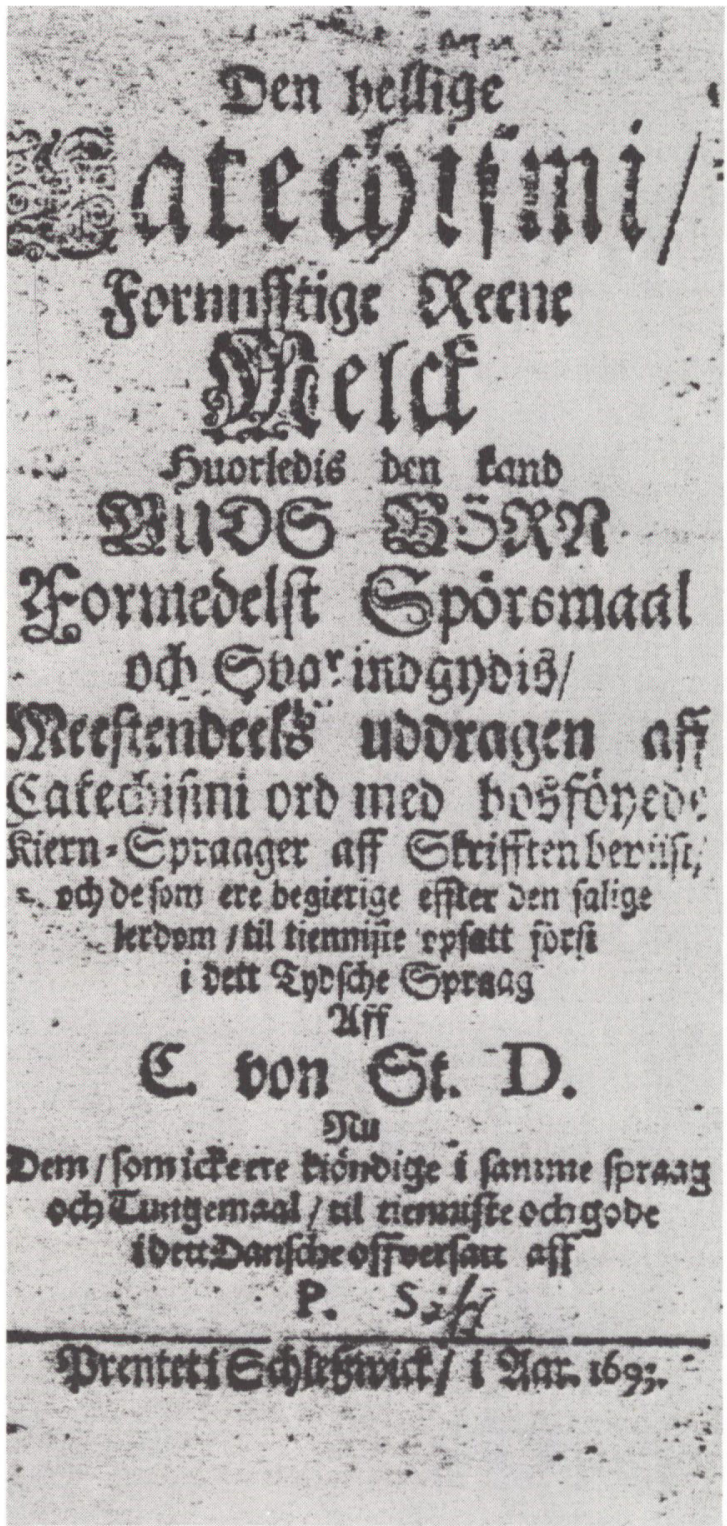

Titelblad pd den katekismus, Andreas Wedel anvendte ved sin konfirmandundervisning 1707. Den lange titel lyder: Den hellige catechismi fornuffige reene melck huorledis den kand Guds barn formedelst sporsmål og svar indgydis. Meestendeels uddragen aff catechismi ord med hosfoyede kiern-språger aff skrifften beviist, och de som ere begierige effter den salige lerdom/til tienniste opsatt forst $i$ dett tydsche språg aff C. von St(öcken) D. $\mathrm{Nu}$ dem, som icke ere kiondige $i$ samme språg och tungemal, til tienniste och gode $i$ dett dansche offversatt aff $P($ aul $)$ $S$ (ass). Prentet $i$ Schlesswick $i$ dr 1693. Kopi af titelblad venligst stillet til rảdighed af pastor emer. Urban Schroder, Varnas. Originalen findes $i$ Universitetsbibliotekets 1. afd., Kobenhawn.

eksamen for menigheden, og børnene i lige måde offentligt skulle konfirmere det løfte, som deres faddere havde gjort på deres vegne ved dåben«. Han havde da svaret grevinden, at denne skik ikke var ham ubekendt, men at han ikke vovede at praktisere den, medmindre han 


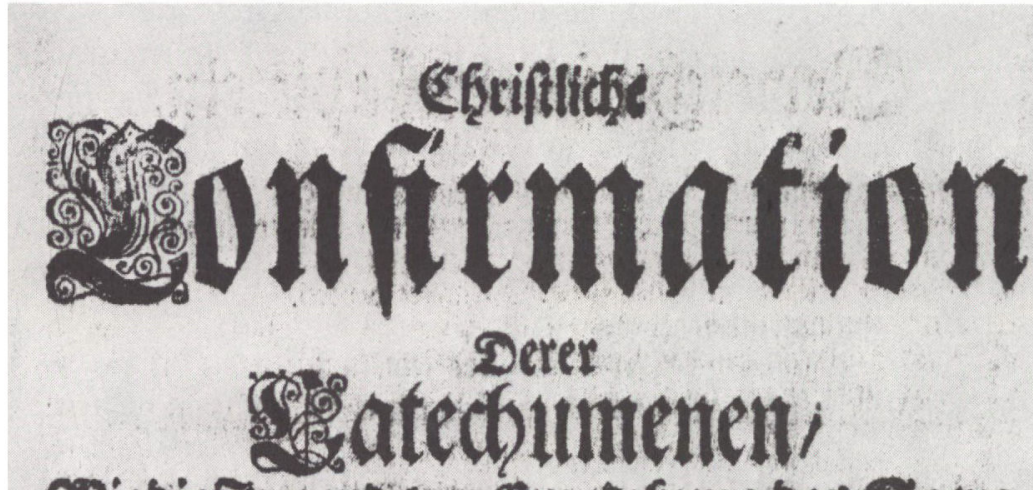

abie bie Sugenb vor cmptafung bos Snera-

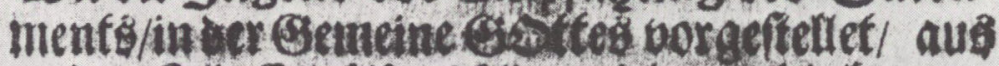
ocm Jjeil Eatedjifaus foll examinite , unb in ibrem Tauff Bub und Cbriftentfum confirmirt weroen.

Sonon Der \&poltel orit an bifber। Fus Der sall Sofirift / uno Antiquitat ber Drientalífóenumo sccioentalifíten sirden ‥

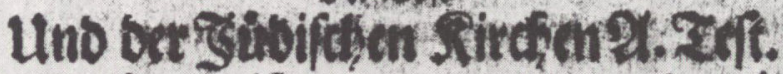

unb ber Daber entfitanoenen Initiasion Det chrobafis ren weltweifen Sjevoen/nebif bevgefingtem Bebenden

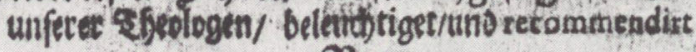

\section{TROGILLO Imntid।

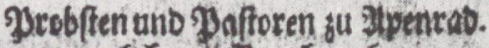

3um andermmabt alffacleat / uno bin uno wieber vermefirt.

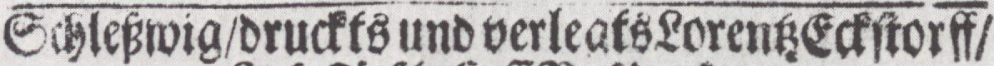

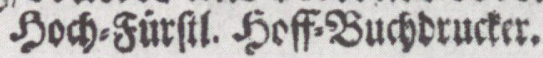

Titelbladet til Abenråprovsten Trogillus Arnkiels vejledning "Christliche Confirmation" fra 1693. 
kunne få sin gejstlige øvrigheds godkendelse heraf. Grevinden havde imidlertid $\mathrm{i}$ vidners nærværelse befalet ham at indføre konfirmationen og havde lovet at drøfte sagen med biskoppen, så at den unge præst ikke skulle få ubehageligheder deraf. Om grevinden har fået talt med biskoppen får stå hen, men Andreas Wedel prøvede i hvert fald konfirmationen en enkelt gang, nemlig onsdag den 30. november 1707. Grevinden var imidlertid død i København allerede den 10 . november, og han kunne derefter ikke vente hjælp fra den kant.

Selve konfirmationen i Daler kirke blev gennemført efter provst i Åbenrå Trogillus Arnkiels udførlige ceremonielle vedledning: „Christliche Confirmation derer Catechumenen ...«, som var udkommet 1693 og som sammen med Arnkiels »Einfältige Katechismusfragen ...« blev brugt overalt $\mathrm{i}$ de hertugelige og kongelige dele af Sønderjylland. Andreas Wedel var naturligvis ganske klar over, at konfirmationen ikke var indført i kongeriget, men da den fandtes overalt i de lutherske provinser i Tyskland, havde han som nævint med den venligt sindede grevindes støtte vovet at gøre forsøget i Daler. Og det har vel heller næppe været selve konfirmationens indførelse, som har vakt det store anstød i menigheden, men nok så meget det offer, som præsten krævede i forbindelse med denne nye kirkelige handling. Da han så også krævede andre nye afgifter eller forhøjelse af bestående afgifter, kom han i konflikt med sin menighed - en konflikt, som endte med et ydmygende nederlag til ham.

\section{Græsning på kirkegården og kirkeværgen Niels Brinks tilsyn}

Det er ofte de små ting, som kan sætte gang i de store. Det var en erfaring, som den unge præst endnu ikke havde gjort, men som han til en rigelighed kom til at sande. I sine krav om accidenser og offer optrådte han med stor frimodighed over for sine sognebørn, men da menigheden vel vanskeligt kunne gennemføre en sag med heldigt udfald på dette grundlag, blev det spørgsmålet om indførelsen af konfirmationen, som blev hovedklagen mod ham. Der kan dog næppe være tvivl om, at for sognefolket var det afgifterne og andre økonomiske mellemværender, der blev det væsentlige motiv til opgøret med præsten. Dette begyndte blot nogle få dage efter svigerfaderens død den 26 . februar 1707, da man beklagede sig over præstens græsning på kirkegården til den myndige, grevelige overinspektør Eberhard Frostberg. Denne lod 
klagen, som ikke ses at være besvaret, gå videre til kirkeværgen i Daler, delefoged Niels Brink, som sammen med to mænd mødte op i præstegården den 11. marts for at meddele Andreas Wedel menighedens klagemål mod ham og få hans bemarkninger hertil. Disse kom skriftligt den 16. marts i en lang, fornærmet skrivelse til overinspektøren. Heri siger Andreas Wedel, at sognefolkets klage med »forlov at melde er løgnagtig og aldrig kan gøres bevislig«. Af skrivelsen, som indeholder mange interessante oplysninger om kirkegårdens tilstand og menighedens opforsel under gudstjenesten, fremgår, at man har været utilfreds med, at præsten og hans forgænger, svigerfaderen, har ladet deres bæster græsse på kirkegården. Ingen har imidlertid klaget til svigerfaderen over, at begravelser og monumenter var blevet ødelagt ved hans bæsters græsning på kirkegården, og Andreas Wedel er i allerhøjeste grad utilfreds med, at menigheden nu efter deres gamle præsts død har klaget, og han går til modangreb ved anvendelse af vendinger og udtryk, som vi genfinder $i$ de hurtigt følgende og mere alvorlige konflikter. Ganske ejendommeligt lyder $\mathrm{i}$ vore øren hans omtale af kirkegårdens anvendelse. »Kirkegårdens fornemste brug er vel denne, at udi dens jord gemmes de afdødes legemer, indtil Guds basuner opvækker dem, men dens anden brug er, at dens græs, som Gud ikke mere der end andetsteds lader gro forgæves og til ingen nytte, af småt fæ opædes, som ikke kan tilføje gravene nogen skade, helst eftersom det med leen ikke kan afslås«. Og dernæst følger en ganske interessant »lignelse«, som han kalder det, og som han mener, sognefolket kan oplyses ved: "Gud har givet dem fødder, hvis fornemste brug er, at de skal bære deres legeme til steder, hvor det kan være Gud til ære, dem selv og deres til gavn og nytte og deres næste til tjeneste. $\mathrm{Nu}$ bruger mange dem til anden brug og lader dem bære sig til krohuse, hvilken brug i sin visse henseende er en misbrug, helst når det sker om søndage og under hellige dage, hvilket desværre her i Daler sogn er alt for gement, og skulle denne misbrugs afskaffelse være jo (dvs. nok) så nyttig og nødvendig som bæsternes afskaffelse af kirkegården. At der jo på andre måder sker stor uskikkelighed og uhøflighed på kirkegården kan ikke nægtes, mestendels dog formedelst deres egen forseelse, thi når de enten fører lig eller følger brudefolk til kirken, da bliver der vel gjort anstalt, at kirkegårdsporten bliver oplukt, men ikke, at den igen bliver tillukt, hvorover svinene uden hinder kunne gå ind på kirkegården og i en time gøre mere skade på godtfolks grave end bæsterne, som kun en halv times tid, tillige medens tjenestefolket har ædt deres davre, er blevet indledt, i mange år kunne gøre, 
så som slig bæsternes græsning på kirkegården aldrig har været over 14 dage, den stund tørvene hjemførtes af mosen. Det er derfor sognemændenes egen skyld, at deres grave fordærves«. Endvidere anfører han, at sognets unge trods hans alvorlige påmindelser under gudstjenesten løber rundt på kirkegården som nogle unge kalve og gør gravene ikke liden skade, medens de ældre sludrer og slikker solskin, indtil sidste salme synges.

Andreas Wedel formoder, at kirkeværge Niels Brink har konciperet klageskrivelsen, og om ham siges, at han er meget syg for at have noget at observere. "Gid han ville observere det, han skulle, Jeg frygter, at han er mere betroet end han er god for at forestå, såsom han er ene om det, hvortil Hans Kongl. Majestæts allernådigste lov forordner tvende «. Hans tilsyn på kirkegården er mangelfuld. Han bør naturligvis sørge for, »at af ufornuftige bæster ingen uhøflighed eller uskikkelighed ved de afdødes grave begås. Bedre var det, at han observerede, hvorledes fornuftige salvo honore (med forlov at sige) sætter deres excrementum og urenhed ved Herrens hellige tempels bygning, den samme såvel som kirkegården til største vanære; thi hvad de ufornuftige bæster reverenter at melde lader efter sig på kirkegården, hvilket er det bedste, hvormed de betaler deres foder, blev altid af stalddrengen ført af vejen, at det ikke skulle ligge nogen til forargelse«. Det var efter præstens mening bedre, at kirkevargen så, at kirkegårdens stendige på en del steder var meget forfaldent, så at både bæster, svin og andet kvæg let kunne gå derover. "Bedre var det, han observerede, at sognefolket ved deres dødes begravelse ikke spolerede bemeldte gærde og borttog stenene deraf til at ligge rundt omkring og på deres grave«. Han foreslår endvidere, at det var bedre, at Niels Brink førte tilsyn med, at sognefolket ikke skar græstørv på kirkegården til at lægge over gravene, men i stedet tog græstørvene uden for kirkegården på »kirkens fortov《. Bedre var det også, mener præsten, at Niels Brink gjorde anstalt til at få den teglovn, som han og andre har opsat på kirkens fortov, lovliggjort og at få den sikret, så at ingen ved nattetid, når de færdedes ad de to veje, som går forbi ovnen, skulle forulykkes, »og der skulle komme blodskyld over den ganske menighed«. Sluttelig giver han udtryk for, at han ikke har onske om at forblive som sognepræst i Daler ret længe. Dette ønske kom imidlertid ikke til at gå i opfyldelse. Eberhard Frostberg gav sig god til til at svare på præstens lange brev. Først den 12. april kom der et henholdende svar, hvori han meddelte, at han ville forelægge sit herskab og den gejstlige øvrighed de mange klagepunkter. Han havde dog ikke kunnet finde beviser for præstens 
påstand om løgnagtige klager og støtter altså her sin delefoged. Han understreger dog, at Daler kirkegård ikke på nogen måde må forurenes eller vanhelliges. Hverken det grevelige herskabs eller den gejstlige øvrigheds reaktion på præstens klager over sine sognebørn kendes dog.

\section{Præsteembedets græsningret til fire kreaturer.}

Meget snart kom en ny konflikt mellem præst og menighed. Allerede tidligt på sommeren 1707 opstod der uenighed om græsningsretten til fire kreaturer, som præsteembedet fra 1560 havde haft på Østerby hede, men som hver enkelt af Andreas Wedels nærmeste forgangere ved overenskomst med bønderne, såvel de schackenborgske som de hertugelige havde fået ændret til, at de fire høveder i præsternes levetid kunne græsse på Østerby Kofælled, der lå syd for byen på begge sider af Tønder-Højervejen. Da svigerfaderen Ægidius Hansen Gram nu var død i februar 1707, gjaldt overenskomsten ikke længere, og de Østerbybønder havde prompte - trods nådsensåret - jaget præsteenkens kreaturer bort fra Kofælled og ud på heden mellem Østerby og Lindskov. Denne hede var imidlertid efter Andreas Wedels formening blevet "fordærvet « som græsningsareal ved, at dele af den i de sidste årtier var blevet taget under plov. Striden blev indanket for det grevelige herskab, og overinspektør Eberhard Frostberg søgte forgæves at få parterne forligt. Der faldt da den 19. juni 1707 en grevelig resolution, som gik ud på, at det kongeligt konfirmerede tingsvidne af 1560 stadig stod ved magt, uanset at Andreas Wedels forgængere ved særlige overenskomster med bønderne havde kunnet græsse de fire kreaturer på Kofælled. Andreas Wedel og svigermoderen måtte herefter foreløbig stille sig tilfreds med græsningen på heden, men Andreas Wedel glemte ikke, som det kan ses af det følgende, græsningen på Kofælled. Disse sager blev dog kun en forsmag på hastigt følgende stridigheder. Fra første færd kom Andreas Wedel i alvorligt modsætningsforhold til sit sogn.

\section{Strid om offer og accidenser}

En væsentlig grund til uoverensstemmelserne må foruden $\mathrm{i}$ præstens stridbare karakter søges $\mathrm{i}$ hans meget dårlige økonomiske forhold. Svigermoderens ubønhørlige krav om indtægterne i nådsensåret medførte, at han ikke blot måtte sørge for, at embedets indtægter blev 
opretholdt, men at de, for at han kunne få et rimeligt udkomme, også måtte øges. Dette er da også baggrunden for de mange mærkelige breve, som han efteråret 1707 og vinteren 1708 sender til en del af sine sognebørn. I et brev dateret den 18. oktober 1707 stævnede han Peder og Mathias Hansen til at give møde i præstegården den følgende dag kl. 2, for at de over for provsten i Møgeltønder, Malthe Junghans kunne forklare, hvorfor de ikke havde givet ham, Andreas Wedel, et offer, som han mente at kunne tilkomme. Næste kendte brev er dateret allehelgensdag, d.v.s. 1. november 1707. Det var stilet til Jochum Christian, en sømand, der stammede fra Gammel Haderslev sogn og som samme dag i Daler var blevet agteviet til Kirsten Simonsdatter af Østerby. I brevet, som han lod degnen overbringe, og hvori han returnerede det af Jochum Christian betalte brudeoffer, begyndte han ganske vist med at lykønske det unge par, men dernæst meddelte han, at han havde fået en rigsdaler for lidt $i$ offer, og han bad derfor brudefolkene betænke, "hvad straf det fører med sig at forurette sin sjælesørger og uden al skyld og brøde ligesom stjæler ham den fortjente løn fra«. Dette brev havde imidlertid ikke den onskede virkning, og derfor stillede præsten, efter at Joachim Christian heller ikke havde præsteret et antageligt juleoffer, sig den 29 . december på ny til sin skrivepult og forfattede et nyt brev til ham. Heri hed det, at det gjorde ham hjerteligt ondt at fornemme, at Jochum Christian var "geråden i så stor vildfarelsesørken og vanvittighedsørken, at I ikke ved, at Gud er en retfærdig dommer, der ikke aleneste hader, men endog ofte håndelig hjemsøger dem, som modvillig og forsætligvis gør hans tjener fortræd og uret, hvilket den daglige forfarenhed nok lærer os af andres eksempler, og jeg ville gerne ønske, at I ikke herpå skulle blive et eksempel, som er ikke uden årsag at befrygte, efterdi I ikke kan blive vis af andres skade«. Han havde dobbelt årsag til påmindelsen. For det første havde hans kone og hendes "compagner søster«, d.v.s. ledsager $i$ deres surfittige karrighed (træske gerrighed) villet have brudesmykket gratis, og han havde kun ofret 4 mark lybsk for sig og brud, hvilket beløb præsten havde returneret via degnen, "såsom sådan et brudeoffer end ikke af hyrdefolk var faldet på vort alter i de 20 år og deroverı. For det andet: »dernæst kommer I på juledag med indlagte mark 1(ybsk); da I dog i $3^{\text {de }}$ somre haver været ude på farten, da imidlertid jeg såvel som min salig formand haver indesluttet Eder $i$ vore forbønner, for hvilken tjeneste jeg i det ringeste kan prætendere 1 mark 1 . for hver sommer. Nan Jensen, som også lige så vel som I, dog ikke af sig selv, men af andres tilskyndelse haver forholdet os den sædvanlige 
rettighed med sit brudeoffer, har dog $\mathrm{i}$ julen bevist sig således, at jeg med hannem i den fald er vel fornøjet, og det må I vel tro, at dersom I ikke mager det ligeså, at Gud vil i fremtiden tage sin lykke og velsignelse fra Eder, som imod Eders sjælesørger og forbedere findes så uskønsom og utaknemmelig«. Jochum Christian kunne altså indtil videre tage sin mark 1 . til sig igen, og præsten ville da $i$ sin bog notere ham for 3 mark forbønspenge ud over de 6 mark, som han var ham skyldig for brudevielsen. "Imidlertid vil jeg håbe, at Gud skal give Eder et andet sindelag, og hvis I ikke vil lade Eder regere derhen af Guds ånd, vil jeg formode, at I ved en god lejlighed og rettens hjælp skal blive tvungen til at gøre det, som I nu vægrer Eder udi. Dette således til efterretning af Eders velmenende sjælesørger og uafladelige forbeder. Andres Wedel.« Her truer præsten altså også med den verdslige øvrighed.

Den Nan Jensen, Andreas Wedel omtaler, var hertugelig undersåt og havde den 6. november 1707 holdt bryllup med Karen Hansdatter, datter af Boel Hanskone og søster til Anders og Hans Hansen, to kloge og lovkyndige bøndersønner, som det snart skulle vise sig at være alt andet end rart for præsten at blive uvenner med. Disse to brødre blev senere bøndernes ordførere både i Daler sognemænds sag mod det grevelige herskab om en forhøjelse af kirketienden og i den årelange såkaldte lagieproces. Begge disse sager, hvorom der skal berettes andetsteds, førtes frem for højesteret. Også ved Nan Jensens og Karen Hansdatters bryllup havde præsten benyttet degnen som budbringer ved opkrævningen af brudeofferet. Men ved deres bryllup kom der et andet moment til. Bruden havde ikke, som skik ellers var på egnen, været prydet med det brudesmykke, som præstekonen udlejede mod et gebyr. Allerede før brylluppet, der som næunt fandt sted den 6. november, havde præsten den 27 . oktober indhentet en erklæring fra birkedommer Christian Thomsen i Møgeltønder og af den fremgår, at præstekonerne der på egnen almindeligvis havde anskaffet et »sømmeligt ornament« til at udsmykke bruden med på hendes »ærensog bryllupsdag" efter landets skik og brug imod en billig betaling. Birkedommeren mente, at det ville vare upassende at afskaffe denne skik uden godkendelse af kirkens patron, d.v.s. det grevelige herskab og af den gejstlige øvrighed. Indtil en sådan ny bestemmelse forelå, anbefalede birkedommeren, at Boel Hanskone og hendes datter samt Simon Hansen Klints datter, som heller ikke havde villet betale præstekonen for leje af brudesmykket, under trussel om straf ikke indførte fremmede brudesmykker $\mathrm{i}$ sognet og lod sig pynte dermed til deres 
bryllupsfest. Det skulle dog være dem tilladt at bruge deres egne smykker, "om de sig dermed kan og vil behjælpe og lade contentere«. Det har de åbenbart villet og kunnet, og præsten blev meget fornærmet herover. Dette viste han blandt andet ved, at han ved Nan Jensens bryllup lod brudeskaren vente i kirken til henimod kl. 11 uden advarsel, hvilket ikke nogen kunne mindes tidligere at vare sket ved en vielse $i$ Daler.

\section{Forvaltning af skriftemål og altergang}

Nan Jensens og Jochum Christians bryllupper gav også anledning til andre besynderlige reaktioner fra præstens side. Han var som næunt meget fortørnet over, at han ikke havde fået det bryllupsoffer, som han mente, han kunne tilkomme fra de to, og noget senere skrev han i et udateret brev til dem, at han havde på fornemmelsen, at de to den følgende dag ville til skrifte og den næstfølgende søndag til alters. Det tilkom ham imidlertid forinden, at wholde en liden samtale med Eders samvittighed og at foreholde dem efterfølgende, om nogen uden samvittigheds besværelse og beskårelse og sin saligheds forspildelse kan gøre sin næste vitterlig uret og dog uden frygt for Guds strenge vrede gå til skrifte og alters eller og om nogen vil fornøje sin fortørnede næste og give ham det, som skyldigheden udkrævede, da han dog kan, ikke heller vil bede om forladelse for sin forseelse, om han kan tillades til det hel. sacraments brug uden at erlange med Judas Ischarioth Guds vrede og forbandelse $i$ steden for hans nåde og velsignelse. Til begge disse spørgsmål vil jeg lade Eders egne samvittigheder give gensvar, eftersom I da begge, både I Nan Jensen og Jochum Christian af Østerby vider Eder skyldige, at I haver gjort mig uret, som er Eders sjælesørger og derfor burde nyde af Eder større kærlighed for Guds og mit hellige embedes skyld end anden Eders næste, så må I vel vogte Eder for Guds straf og vrede, som vist overhænger alle ulydige og uretfærdige, der kommer deres sjælesørgere til at sukke over deres fortrædelighed. Dette må I også vide, at Gud haver givet mig som hans uværdige tjener lige så vel magt at binde synden på de ubodfærdige og at forkynde dem vreden og fordømmelsen som at løse den på de bodfærdige og at forkynde dem syndernes forladelse og saligheden. Det skal derfor være mit velmente råd, at førend I indstiller Eder til skriftestolen, I tilforne stiller mig tilfreds og affinder Eder i det gode, at jeg ikke skal have årsag imod min vilje at lade Eder se mit hel(lige) 
embedes myndighed, hvilken jeg ret vel vil vide at forsvare, både for den jordiske dommer så og for den himmelske allerhøjeste dommer, for hvis domstol vi alle i sin tid skulle åbenbares. Anders Wedel. Christian Jensen degn haver at forkynde dette for Nan Jensen og Jochum Christian i Østerby om middagstider i dag og at meddele dem deraf, om de forlanger, en kopi for betaling etc."

Andreas Wedel optræder her som en anden Sct. Peter, der er i besiddelse af nøglerne til himmeriges porte, og det er forståeligt, at de to mænd enten hver for sig eller $\mathrm{i}$ fællesskab har villet betale degnen for en kopi af denne besynderlige skrivelse, som bærer præg af, at den er skrevet af en mand, som er helt ude af balance. Det var et godt dokument for Anders Hansen at have i hænde, når der skulle klages over præsten.

Med dette skrappe brev var sagen dog ikke slut for de to formastelige, som ikke ville betale bryllupsofferet. De flyttede kort derefter bort fra sognet, Nan Jensen til Koldby i Hjerpsted sogn og Jochum Christian til Visby sogn. Ved en sådan flytning skulle de have deres "skudsmål«, d.v.s. en attest fra præsten om, hvornår de sidst havde været til alters, og før de havde præsenteret denne attest for deres nye sognepræst, kunne de og deres hustruer ikke komme til alters i deres nye sogn. ${ }^{5}$ Trods gentagne henvendelser fra de to mænd nægtede Andreas Wedel at udstede de ønskede skudsmål, før han havde fået brudeofferet fra dem. Ved Jochum Christians sidste besøg hos præsten den 6. marts 1708 havde han ved afskeden ønsket ham »Gud i vold «, hvilken hilsen imidlertid blev gengældt med ordene: "Så længe, som I bliver på denne vej, er I udi Satans vold.« Endnu så sent som den 12. juli 1708 var Anders Hansen mødt op i præstegården for på sin svoger Nan Jensens vegne at afkræve hans skudsmål, men præsten havde da sagt, at Nan havde fået det. Da Anders Hansen benægtede dette, havde præsten sagt til ham: "Det skal I have løgn som løgner og en skælm.»

\section{Betaling for ligprædiken}

Også ved begravelser viste præsten sin interesse for den økonomiske side af sagen. Ved Sidsel Bohs, en 86-årig blind kones død den 31. januar 1708 havde han forud for begravelsen hos svigersønnen Christian Jessen villet have oplyst, hvor meget familien ville give for ligprædikenen. Han havde da - som han den 3. februar beklager sig over i et brev til Hans Japsen, søn af afdøde - fået et »hånligt« tilbud, som var 
mindre end hans forgænger og han selv havde fået ved ligprædikener over kådnere, d.v.s. husmænd. Præsten havde derfor forlangt et honorar på 3 rigsdaler for ligprædikenen, hvorefter Christian Jessen havde bestemt, at liget skulle føres til kirken og nedsænkes $\mathrm{i}$ jorden uden klang og sang. Ikke desto mindre havde Andreas Wedel dog i håb om, at Christian Jessen ville betænke sig, udarbejdet en ligprædiken. Han havde dog ikke hørt noget fra ham, og præsten henvendte sig derfor nu til Hans Japsen, for at denne kunne irettesætte svogeren, "og som billigt skamme ham ud, at han i den sted, han burde at takke Gud velinderlig, fordi han så nådelig har hjulpen det sal. menneske fra hendes langvarige leje og ham selv fra et svært huskors, han da findes utaknemmelig med slig surfittighed (d.v.s. nærighed) mod sin sjælesørger og Guds tjener, hvormed han kan nøde Gud til at hjemsøge hans hus med et kors, som er værre end dette. Om han skulle give mig en mark l. for hver gang, jeg har betjent hende på hendes sygeseng, som på andre steder vel er manér og af en del Guds børn her i sognet også sket, så han kan regne til, hvad jeg har for prædiken at holde. Hermed Gud befalet af Eders hulde sjælesørger og forbeder Andreas Wedel. Daler d. 3. febr. 1708.«

\section{Præstetiende og offer}

Andreas Wedel var ikke blot nøjeregnende med betalingen af de enkelte accidenser og sportler, men også mere generelt med betalingen af præstetienden, og også i denne forbindelse anvendte eller søgte han i hvert fald at anvende kirkelige disciplinærstraffe $i$ form af at nægte modvillige betalere adgang til alterets sakramente. I en konflikt, som havde medført ordskifte eller skænderi i kirken om præstetienden m.m. sendte han 2. december 1707 brev til den ansete gårdmand Hans Kannikus i Østerby. Han skriver heri, at han har hørt, at Hans Kannikus den følgende dag vil til skrifte, og at det derfor tilkom ham som hans sjælesørger, nom I ikke selv forstår det, at sige Eder, hvad en kristens sande omvendelse udfordrer, navnlig at fortryde sine forseelser og til sådan fortrydelses udvisning at bede dem om forladelse, som man ved forsætlig vis har gjort uret eller fortræd, være sig hvad tilfælde det være kan efter de klare og bare sande Guds ord og Guds hørres (sic!) hellige eksempler. Da som I vel selv ved, at jeg på mit hellige embedes vegne, haver tiltale til Eder for nogle grove og unyttige ord, som I udi vor kristen menigheds forsamling afvigte den 5 . oktober 
meget ubetænkeligen udøste og sagen allerede hos hans velærværdighed, provsten udi Møgeltønder, er gjort anhængig, så kan I vel selv forstå, at I inden sagens udførsel til skriftemål og altergang ikke kan tillades uden Eders og største skade på sjælens vegne. I kan herhos være forsikret på, at jeg herunder intet andet søger end mit hellige embedes myndighed at holde ved lige og Eders saligheds opbyggelse at søge, så som jeg for min person aldeles ikke er Eders persons fjende, men på mit embeds vegne bør være Eders synds, ja Satans fjende, som ved denne Eders forargelse har ville hindre mig i mit embede, som sigter hen til hans riges nedbrydelse iblandt os. Gud befalet af Daler præstegård d. 2. december anno 1707. Eders uafladelige forbeder og tro sjælesørger Andres Wedel«.

Hans Kannikus, som man ellers har indtryk af, var en mand, som vidste, hvad han ville, kunne imidlertid ikke stå for dette pres fra sin sognepræst og sandsynligvis også fra provsten. I hvert fald sluttede han et forlig, en kontrakt med præsten om deres økonomiske mellemværende. Forliget er udateret, men er formentlig afsluttet nogle dage efter præstens brev, altså i december 1707. Overenskomsten er ikke uinteressant, idet man her får et samlet overblik over, hvilke afgifter en almindelig fæstegård skulle præstere til præsten, og den skal derfor gengives her $\mathrm{i}$ sin fulde ordlyd: "1) Betaler jeg Hans Kannikus min datters offer (til) min kære hr. sjælesørger for påske- og pinseoffer med 10 sk. 2) Forpligter jeg mig til altid herefter at ofre min sjælesørger hver offerdag $8 \mathrm{sk}$. for mig, $8 \mathrm{sk}$. for min hustru og $5 \mathrm{sk}$. for hver (af) mine børn, som er på kost og i tjeneste hos mig, så længe de går her til Guds bord. 3) Lover jeg årlig om St. Martensdag at levere til min kære sjælesørger i steden for det tiendekorn, rug og byg, som hannem tilkommer, 1 tønde rug og 14 skpr. byg; i hvad jeg havre, tader ${ }^{6}$ eller ærter kan høste, deraf lover jeg hannem rigtig den 30. kærv at tilføre lige fra ageren til præstegården, at det ikke $\mathrm{i}$ mit hus skal få skade enten af svin eller af gæs, som dette kunne overløbe. Så lover jeg og årligen, straks efter sæden er gjort, at give hannem til kende, hvo af kådnere eller inderster enten haver sået til halv med mig eller hvor mange skæpper sæd, de af mig kunne have i hyre, at han sin tienderigtighed deraf hos hannem kunne vide at indkræve. 4) Lover jeg ermeldte min kære sjælesørger, at jeg hverken hemmelig eller åbenbar vil være hannem imod enten $i$ hans embede eller uden hans embede - $i$ særdeleshed hvad de 4 nøds græsning på Østerby kofælled eller anden hans rettighed, som hans sal. formand har nydt før hannem, og at jeg hverken med råd eller dåd vil være nogens onde opsæt eller anslag 
mod hannem behjælpelig. 5) Tilbyder jeg mig efterdags herefter at give min kære sjælesørger, så længe både han og jeg lever, hver 15 . unge gås om mikkelsdag og derhos troligen hjælpe til, at han også hans levnets tid nyder det som en frivillig gave af de andre bymænd, hvoraf ingen rettighed skal gøres. 6) Udlover jeg til de fattige her i sognet $\frac{1}{2}$ td. rug og en halv tønde malt, hvilken jeg straks til præsten vil aflægge, at han det før jul til de fattige kan uddele. - Derimod lover jeg, hr. Andres Wedel 1) at jeg på mit hellige embedes vegne vil tilgive Hans Kannikus sin begangne grove forseelse, som han forleden 5 . oktober i Daler kirke i menigmands påhør mod mit hellige embede begik, 2) at jeg hvilken (hverken) nu eller herefter vil klage ham an enten for verdslig eller gejstlig øvrighed, men lade den sag være aldeles død og magtesløs, såfremt Hans Kannikus holder sig ubrødelig efter oven skrevne punkter, 3) at jeg vil holde disse punkter hos mig selv og ikke lade hver løbe med det Hans Kannikus til nogen skade eller ulempe, 4) at jeg ellers vil holde Hans Kannikus for min ven og ikke hade ham i nogen måde for sin begangne forseelse, men tjene hannem inden og uden mit embede, hvor og når han det sømmelig begærer.«

\section{Adventsgudtjenester 1707}

Dermed var Hans Kannikus til en vis grad pacificeret, men også kun til en vis grad, idet Anders Hansen, da anklagepunkterne mod Andreas Wedel blev formuleret, også kunne tage denne sag med. Men ud over disse breve og dokumenter om præstens krav på offer, accidenser og tiende kunne Anders Hansen og vidnerne ved de afhøringer, som på biskop Christian Muus' foranledning fandt sted på Møgeltønder birketing den 15.-16. august 1708, også fortælle om Andreas Wedels ret så kraftige opfordringer ved gudstjenesterne 3. og 4. søndag i advent 1707 om at give ham et ordentligt offer. Med udgangspunkt i evangeliet til 3. søndag $\mathrm{i}$ advent (Mathæus 11. kap., 2-10 vers), hvor de »bløde klæder« omtales, havde præsten prædiket om klædedragten og havde da sagt: "De kommer med deres gyldenstykkes luer op til Herrens alter med en søsling; ej hvor dejlig lover (d.v.s. tager sig ud) det som en død flue udi en apotekers krukke.« Og den følgende søndag, den 18. december, skulle han ifølge Anders Hansens klage til biskoppen efter prædikenen, »da det var oplæst, som skulle oplæses«, have holdt en lang tale om sit offer, bl.a. med følgende ord: "En dytken ${ }^{7}$ at ofre er en skammelig offer; det er offer til en svinehyrde og ikke til en Herrens 
tjener.« Derefter havde han læst et forslag op om, hvorledes han mente ofret skulle være, et forslag, som var godkendt af overinspektør Eberhard Frostberg på Schackenborg. Forslaget, som minder om overenskomsten med Hans Kannikus, gik ud på, at de, der havde mere end 6 tønder hartkorn til jul, påske og pinse skulle ofre for sig selv og deres hustruer, hver 8 sk., for hver søn eller datter, som gik til Guds bord og som var på kost hos forældrene, skulle der gives 5 sk. De, som havde en gård på 3-6 tønder hartkorn, skulle give henholdsvis 7 og 4 sk. og de, som havde en gård under 3 tønder hartkorn skulle give henholdsvis 6 og 4 sk. Kådnere og inderster, som havde god næring eller var gode håndvarkere, skulle give henholdsvis 5 og 3 sk., medens andre kådnere og inderster, som var gifte, kunne nøjes med henholdsvis 4 sk. for mand og kone og 3 sk. for hjemmeværende voksent barn. Havde nogen flere hjemmeværende børn, reduceredes offeret med 1 sk. pr. barn. Ugifte inderster og tjenestefolk skulle som sædvanligt give 3 sk. hver offerdag. "Dog så som der er stor forskel på tjenestefolkets løn, burde der og være forskel på deres offer til præsten, såsom det er det eneste, som de det ganske år have til hannem at udgive«. En enkes ældste søn skulle give husbondens offer, medens aftægtsfolk skulle ofre som børn på stavnen. I deres klageskrivelse af 8. marts 1708 siger Østerby-folkene, at præsten ved denne lejlighed, den 4. søndag i advent, skulle have sagt, at offeret "skulle I lægge mig udi sedler med Eders navne udi, og dersom I ikke det gør, da vil jeg søge øvrighed, og det skal komme ud ved pantemænd, nu jeg haver mindet jer om et og andet, men det sidste skulle I vel antage for gerrighed, men derom spørges nu, om det er gerrighed at begære sin rettighed eller at forholde den, når man ikke kan gøre sko efter hver deres hoveder. Kan de ikke ellers nå det, da skal de, når deres koner går udi kirken, korte det af i den rettighed, som de før have givet og siden også med brudefolk også at tage fra den rettighed, som de før haver given, så jeg ved ikke, hvoraf de have sådant. Af Hans Kgl. Majestæt have de det ikke og ikke heller af øvrighed, ikke af sal. grevindens anordning; men dermed ville de rette sig selv og griber så ind $\mathrm{i}$ kongens respekt også de, som ofrer med brudefolk, så som gamle mænd og koner og unge karle og piger; voksne folk, som snart kunne have min tjeneste behov, de kommer med deres gyldenstykkes hat med 1 søsling, hvormed de vanærer Herrens alter, Herrens tjener til vide (d.v.s. til skade). Haver I ikke fået nok på det sted, at I kunne anderledes ære dem, da kan I tage dem med Eder igen og gå med dem til kros og se, hvorvidt det kunne strække sig; den ene forarger den anden, dermed piller de barken 
af de små træer, så de ikke kunne få deres fremvækst, bart ud at sige, da kommer de store de små dertil. Jeg byder trods, hvor det skal være både for verdslig eller gejstlig øvrighed; dersom de ikke omvende sig, da må de vente sig forbandelse og siden evig fordømmelse; det var bedre at gå bag en fårehjord og give dem den legemlige føde end at være lærer og åndelig hyrde iblandt sådanne genstridige bukke og splidagtige geder, men det er jo forjættelsen, at slangen og dens sæd skulle bide os i hælen. Hvi skulle vi vente os bedre lykke. De haver så forfulgt profeterne, som vare før Eder. De, som adlyde mig, til Eder haver jeg en anden tale. Over Eder og over Eders huse skal lykke og velsignelse og siden den evige salighed være.«

Referatet af præstens tale udmærker sig just ikke ved sproglig klarhed. Ofte virker det lidt stikordsagtigt, som om det kunne være sammenflikket af flere tilhøreres notater foretaget under selve talen, men der er visse ord og vendinger, som f.eks. den gyldenstykkes lue eller hat, bemærkningerne om fărehyrden og fărehjorden og om pengestykket »dytken«, som går igen i vidneudsagnene i birkeretten i Møgeltønder. Både Anders og Hans Hansen forstod ellers nok at formulere sig på prent, og deres breve er almindeligvis skrevet i et mere forståeligt sprog, end de to studerede teologer Andreas Wedel og Malthe Junghans formåede det. I sin forsvarsskrivelse til biskoppen af 8. maj anførte Andreas Wedel til sin undskyldning, at forslaget om accidenserne ikke var fremført som nogen befaling. Der var ikke blevet sagt andet, «end at hver kunne vide, hvad der er billigt og skikkeligt, hvilket en del her i menigheden både tilforn og endnu har ladet sig befalde«. Hvor nøjeregnende Andreas Wedel var med accidenserne, får man i øvrigt et yderligere indtryk af, når man ser, at han ikke ville nøjes med, at konfirmanderne ofrede 1 mark danske i stedet for en mark lybsk, som var noget mere værd, at han i kirkedøren havde ladet degnen opkræve et offer af konerne til knapperne i sin præstekjole, og at han den 19. oktober 1707 havde ladet to Østerby-folk indstævne for provsten, fordi deres koner - som kirkegangskoner - ikke havde ofret til præstens tilfredshed.

\section{Bøndernes taktik og konfirmationen 1707}

Andreas Wedels mærkværdige optræden i sine krav om øgede indtægter, således som de blev fremsat i breve og prædikener, har næppe været nok for Anders og Hans Hansen til med held at kunne få hans 
overordnede gejstlige til at give ham en irettesættelse eller til at få ham dømt, så meget desto mere som hans nærmeste foresatte, provst Malthe Junghans holdt sin beskyttende hånd over ham. Men i forsøget på at indføre konfirmationen havde Andreas Wedel ganske klart overtrådt bestemmelser i Danske Lov, og de unge lovkyndige brødre har heri øjnet en chance til at få præsten dømt ikke blot for konfirmationen, men også for hans opkrævning af accidenser og afgifter. Forsøget på indførelsen af konfirmationen har nok ikke spillet den helt store rolle for de to brødre; men de så klart, at det kunne blive det afgørende moment $i$ at få en sag mod præsten gennemført med heldigt udfald. Derfor blev klageskrivelsen af 8. marts til biskop Christian Muus i Ribe, som var konciperet af Anders Hansen, men egenhændigt underskrevet af Jørgen Nielsen, Hans Boesen, Laurids Matthiesen og $\mathrm{H}$. Boesen, ${ }^{8}$ indledt med en redegørelse for, hvorledes præsten den 30. november 1707 havde praktiseret den første konfirmation i Daler kirke. Også ved vidneafhøringen på Møgeltønder birketing den 16. august 1708 , som blev foretaget på foranledning af biskoppen, fik konfirmationen en fremtrædende plads. Man făr et klart billede af, hvad der foregik ved den lejlighed. Præsten havde nægtet at tage de unge til skrifte, før de kunne den nye, trykte katekismus, og han havde søndagen forud for konfirmationen den 30 . november tilsagt menigheden til at give møde. Konfirmanderne skulle møde med deres forældre og faddere. Præsten havde så på selve konfirmationsdagen talt på kirkegulvet til de unge og havde derefter overhørt dem i den trykte katekismus, men også »efter sin egen fri vilje«. Her havde han bl.a. ved gennemgangen af det 4 . bud, der som bekendt lyder: "Du skal ære din fader og din moder«, sagt, »at de skulle ære og lyde ham (præsten) mere end deres naturlige forældre, fordi de kunne ikkun give dem det timelige og han derimod kunne give dem det åndelige«. Efter overhøringen havde præsten så taget de 12 konfirmander med op til alteret, hvor han ssagde, at han ville kende dem dygtige, dog med den vilkår, at de 1) skulle sværge på nogle poster, som han opregnede for dem, og de måtte sige efter og derpå med oprakte fingre aflægge deres ed og derpå straks den ene efter den anden at gå til ham og give ham deres hånd og så at gå om alteret at ofre, og en da, som intet havde at ofre, ville gå tilbage, da tog han hende med magt og drev hende med de andre og sagde: Gå ikkun med. Du bliver intet værre deraf. Da dette var gjort, stillede han dem udi en rad, thi de vare 12 personer og lagde sin hånd på enhver af dem og sagde til en efter anden: Annam den Hel. (lige) Ånd, hvorpå du nu forsikres ved min, Guds ringeste 
tjeners, håndspålæggelse. Herudover blev menigheden ganske underlig, eftersom de aldrig set eller hørt sligt, siden den rene evangeliske lærdom af Guds nåde blev åbenbaret«. Sådan foregik altså den første konfirmation i Daler kirke 1707, og menigheden ville vel næppe være blevet så "ganske underlig«, med mindre konfirmationen havde været ledsaget af offer til præsten, og denne ikke havde stillet sine tidligere omtalte krav om accidenser og offer.

Alle klagerne over Andreas Wedel blev omhyggeligt specificeret $\mathrm{i}$ klageskrivelsen af 8 . marts 1708, som af "soldat « Anders Hansen blev overrakt til biskop Muus, og skrivelsen var bilagt kopier af de breve, som Andreas Wedel havde sendt til sine sognebørn. Samme dag blev også fremsendt en klage fra Nan Jensen og Jochum Christian over, at de ikke havde kunnet få de ønskede skudsmål fra præsten. Det var alvorlige anklager, og derfor fremsendte biskoppen 14. marts klageskrivelserne til provst Malthe Junghans, for at han kunne foretage en nærmere undersøgelse af de enkelte klagepunkter.

\section{Provst Junghans' besøg i Daler palmesøndag 1708}

Provsten besluttede da at tage til Daler for på stedet at få nærmere oplysninger og vel også for om muligt at pacificere klagerne. Dette møde fandt sted $\mathrm{i}$ forbindelse med gudstjenesten palmesøndag, d.v.s. 1. april 1708. Forud for sammenkomsten havde Anders Hansen den 31. marts udarbejdet en omfangsrig skriftlig redegørelse, som han på samtlige schackenborgske og hertugelige sogneboeres vegne skulle overrække provsten den følgende dag. I denne redegørelse, hvori det siges, at det var dem »hjerteligt kært«, at provsten var kommet til stede for at blive orienteret om sagen, blev derefter anklagerne mod sognepræsten opregnet i 8 eller 9 punkter; men provsten nagtede at modtage brevet med det omfangsrige bilagsmateriale.

I stedet indsendte Anders Hansen da den 8. april en omfattende redegørelse til biskoppen, hvori han forklarede, at provst Junghans havde nægtet at modtage klagernes skriftlige redegørelse og bilagene hertil. Endvidere redegjorde han for begivenhederne i kirken palmesøndag, og provstens tale efter den egentlige gudstjeneste refereres. Heri havde provsten forsvaret den unge præst og havde bl.a. også sagt, at i forrige tider havde sognefolkene været kærlige mod deres præster, og at man da havde kunnet give dem alt for »løgn og fabel«, medens de nu, da de kunne høre Guds ord, var så karrige og stridige, at en 
Herrens tjener måtte sukke derover. De var så dygtige til at skrive op; men det havde været bedre, om de havde gemt noget, som de selv kunne have gavn af. Derefter havde provsten læst deres klageskrivelse til biskoppen op, og færdig hermed var han begyndt at råbe op, wikke som han var kommen at forhøre sagen, men meget mere som han ville forfærde menigheden.« Da Anders Hansen derefter ville overrække ham sin uddybende redegørelse om sagen, nægtede han at modtage den, idet han svarede: "Hvad har jeg dermed at bestille. I skulle kommet til mig tilforne og råbte: Drager mig det til minde, at han forhindrer mig udi mit embede.« Anders Hansen var da gået ind i sit stolestade igen, og provsten fik derefter bekræftet underskrifterne på klageskrivelsen til biskoppen af 8 . marts. Da han havde "gennemløbet" det meste af mændenes stolestader og »med hårde ord « havde forhørt dem om, hvad der var foregået $\mathrm{i}$ kirken ved konfirmationshandlingen, blev han bedt om ikke at forivre sig og om at modtage den nye redegørelse, hvad han dog afviste. Han havde da råbt: "Hvad mener I, at vi er kættere eller vildfarendes lærere, at vi ville føre en anden religion.« Sluttelig havde han dog sagt, at de kunne komme til ham

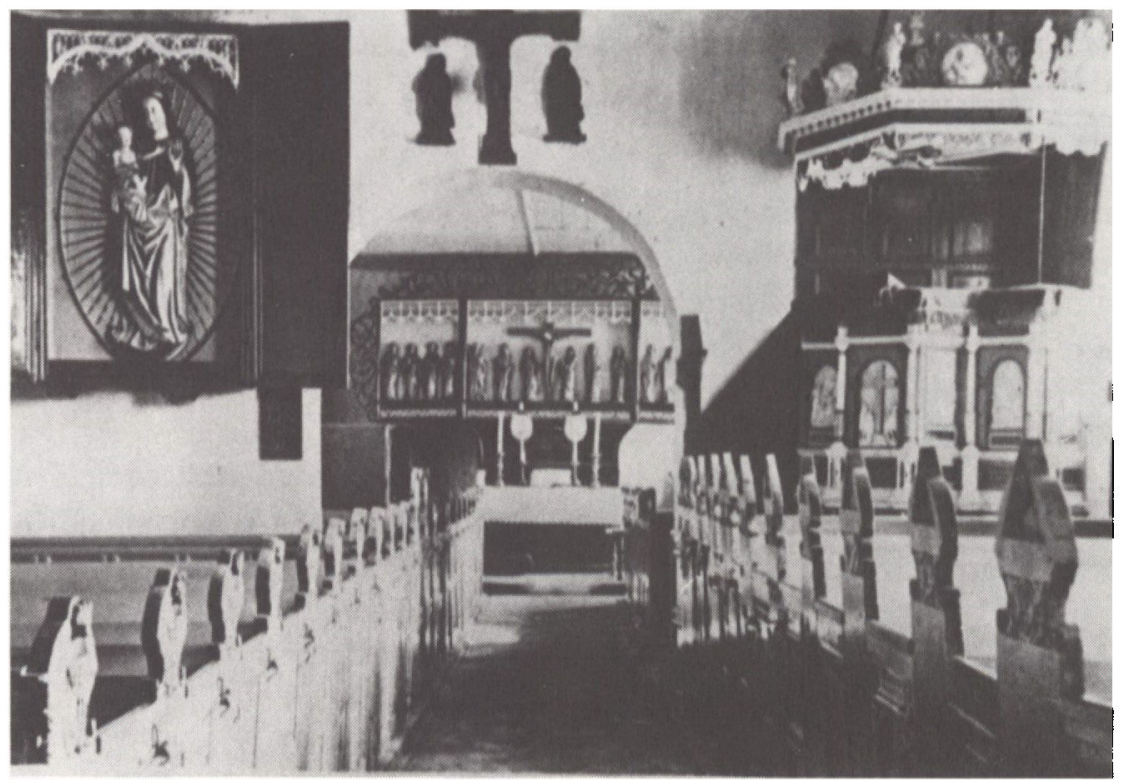

Daler kirkes indre, set mod ost. T.v. den smukke tavle, hvorfra Jomfru Maria sikkert med store, undrende ojne har set ned pd optrinene pd midtergang og $i$ mandsstolestaderne mellem provst, prast og menighed 1707-08. Historiske Samlinger for Sonderjylland. 


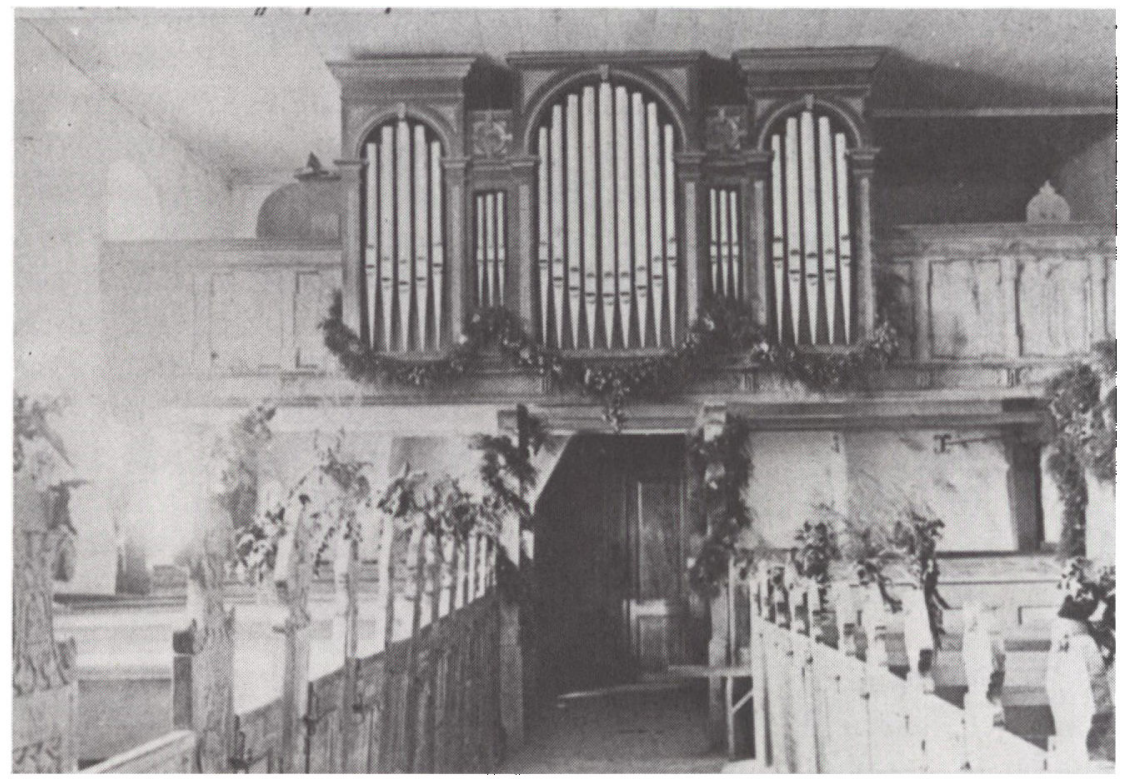

Daler kirkes indre, set mod vest ca. 1920. Pulpituret var endnu ikke opsat under stridighederne 1707-09, men blev det under menighedens protest et par ar senere. Det var nyt 1713, men doren til det var $i$ nogle dr som folge af andre stridigheder tilspigret. Orgelet er fra 1893. Fot. Johs. Timm, Tonder. Historiske Samlinger for Sonderjylland.

med skrivelsen i præstegården. Efter at denne seance var overstået, havde provsten kaldt børnene frem til sig for at overhøre dem, og da han kom til det fjerde bud, forklarede han det på samme måde, som Andreas Wedel havde gjort det. De skulle ære ham mere end forældrene. "Han sagde det, han ville forsvare det, de (nemlig provst og præst) er dobbelt ære værd, er det ikke den Helligånds ord. Og der han sagde disse ord, havde han vendt sig fra bornene ned ad til menigheden. $\mathrm{Nu}$ er det ikke os uvitterligt, at det var den Helligånds ord, men hvad de hører til det fjerde bud imellem forældrene og børnene, det vide vi ikke, og derfor spurgte Anders Hansen af Østerby: Om jeg ville give mig udi den hellige ægteskabs stand, hvem skal jeg da mest spørge til råds og adlyde - præsten eller mine kødelige forældre. Da råbte han: Her er intet at bestille, tager mig min kæp og løb så ud af kirken, dog at der ikke én talede hannem et eneste ord til, både der han prædikede og der han oplæste brevene eller der han overhørte børnene uden det samme ord, og han dog gjorde sådan en bulder og 
alarm, som aldrig nogen kan erindre udi vores menighed at være tildraget af nogen gejstlig mand tilforne«. Brevet til biskoppen slutter med, at Anders Hansen på menighedens vegne beder biskoppen om at formane provsten til, når han på embeds vegne har noget at forrette hos dem, at han da ikke skulle være »krigs, men sædelig og skikkelig«.

Det er jo ikke et helt almindeligt brev, som en gemen militssoldat som Anders Hansen nogle få dage efter det dramatiske optrin i Daler kirke skrev og fik overbragt til biskop Muus. Denne har nok undret sig lidt, men var tydeligvis også irriteret over, at provst Junghans ikke omgående havde reageret på hans ordre om indberetning. Derfor umiddelbart efter at biskoppen havde modtaget Anders Hansens brev, skrev han den 14. april til grev Schack, kirkens patron, der blev orienteret om sagen ved, at hele bilagsmaterialet blev medsendt, og han blev underrettet om, at biskoppen endnu ikke havde fået de krævede indberetninger fra provst og præst. Sagen forekom i øvrigt biskoppen at være af en sådan beskaffenhed, at den burde forelægges kongen. Da Daler jo imidlertid lå i det schackenborgske grevskab, ville han dog først høre, hvorledes greven så på mærkværdighederne. Vi ved ikke, hvad greven har svaret, men han har dog næppe anbefalet en forelæggelse for kongen. Derimod har han nok givet provst og præst en skarp påmindelse om at få indberetningerne ekspederet snarest.

\section{Andreas Wedels svar på anklagerne 8. maj 1708}

Andreas Wedel havde dog først sin klar den 8. maj, sandsynligvis efter en forudgående samtale med biskoppen. Det blev en meget fyldig beretning, hvor han punkt for punkt fremsætter sine bemærkninger til menighedens anklager mod ham. Hans redegørelse for konfirmationen er refereret indledningsvis og vedrørende sine udtalelser om accidenserne 4. søndag i advent anførte han, at han blot havde udtrykt sin utilfredshed med menighedens betaling af den visse og uvisse indkomst. Han henviste $i$ denne forbindelse til en indberetning til biskoppen af 22. juli $\mathbf{1 7 0 7}$ om kaldets indkomster. Han havde i sin tale henvist til, at de formuendes offer på de tre store højtider var ringe og hemmeligt, samt at det ikke var efter kristen billighed. Han havde i præstearkivet fundet en kopi af en klage fra sin forgænger og svigerfader Ægidius Hansen Gram, hvori denne havde stillet lignende forslag til det grevelige herskab, og at enkegrevinden derefter med sin egenhændige påskrift havde beordret de schackenborgske undersåtter, hvis de ikke var ufor- 
muende, at ofre 8 sk. på alteret. Imidlertid var det forekommet Andreas Wedel urimeligt, at alle skulle betale lige meget, og havde derfor indsendt et differentieret ændringsforslag til greven, og det var dette ændringsforslag, der var blevet godkendt af overinspektør Eberhard Frostberg. I øvrigt var det ikke fremført for menigheden som en befaling, men netop som et forslag, hvorefter det kunne stå enhver frit at handle derefter eller ikke.

Der var mange ting i menighedens klageskrivelse til biskoppen, som ifølge Andreas Wedels beretning ikke var bevislige, »og måtte koncipienten vel skamme sig, at han efter en ærlig præstemands mund har sammenskreven sådant, hvorudi ingen connexion (sammenhæng) er og ingen kan finde sig (hitte rede i), så som det ene er sammenblandet med det andet«. Han kunne fremlægge manuskriptet til talen 4. søndag $i$ advent, "som kan give fuldkommen underretning om årsagen, hvorfor disse få er blevet oprørt, sc. (nemlig) fordi jeg efter deres mening for dristig og uden frygt har ført den Helligånds embede at straffe synden«. Om Nan Jensen og Jochum Christian oplyste Wedel, at de omkring Petersdag, d.v.s. 22. februar, var flyttet fra sognet. De havde trods påmindelser ikke villet betale det sædvanlige brudeoffer, og da præsteenken, Andreas Wedels svigermoder, i nådsensåret ikke var tilfreds med den formindskede indtægt, havde han ladet degnen bringe de penge, som var betalt, retur med krav om betaling af det fulde brudeoffer, så meget desto mere som de to personer var "ved gode midler" og havde holdt stort bryllup. Da de to brudgomme nogen tid derefter ville til skrifte og alters, havde han derfor mindet dem om den uret, de havde begået mod ham og formanet dem til at tage deres samvittighed og kristendomspligt i agt. Formaningen hjalp imidlertid ikke, og han havde derfor for fredens skyld affundet sig med deres vægring mod at betale brudeofret, indtil de var kommet for at bede om deres skudsmål. Han havde da igen formanet dem til ikke at være så trodsige med at nægte ham det, som andre hverken havde nægtet forgængeren eller ham. De ville imidlertid ikke bekvemme sig til nogen billighed og derfor »bekender jeg, at jeg efter enkens begæring nægtede dem deres skudsmål, helst eftersom de ikke leverede mig øvrighedspas, hvorpå jeg slig skudsmål efter Hans Kgl. Maj's allernådigste forordning om skudsmål skulle forfatte, hvilke forordninger tillige med andre flere, gejstligheden angående, mig nogle dage tilforn blev lånt af en god ven, ellers jeg snart af uvidenhed kunne have forset mig, såsom jeg tilforne intet vidste deraf at sige«. Han tog endvidere stilling til nogle sager, som ikke er nævnt i Østerby-bøndernes klageskrift. Det ene drejede 
sig om et fortroligt møde på Schackenborg for et års tid siden mellem overinspektør Eberhard Frostberg, provst Malthe Junghans, sognepræst i Emmerlev Marcus Kiel og Andreas Wedel, som bønderne havde fået kendskab til, til trods for at det var aftalt, at dokumenterne $\mathrm{i}$ denne sag skulle tilintetgøres. Hvad denne sag i øvrigt gik ud på, ses ikke af de breve, som blev fremlagt under møderne på Møgeltønder birketing. Andreas Wedel kunne endvidere over for biskoppen til sin undskyldning oplyse, at han havde eftergivet kirkegangsofferet af en "surfittig«, d.v.s. nærig kvinde, og at en anden havde fået eftergivet offeret til påske og pinse. Med hensyn til betalingen for forbønnerne for Jochum Christian oplyste Wedel, at det her drejede sig om en gammel rettighed, og at ingen i hans tid som præst i Daler - undtagen Jochum - havde vægret sig ved at betale. Han skulle for hver sommer, han havde været til søs - og han havde været borte i tre - give præsten en mark lybsk til "diskretion" ved sin hjemkomst; men han havde imidlertid sidste juledag kun ofret en mark lybsk, »hvorved enken, så som det var i hendes nådens år, heller ikke kunne være fornøjet«. Ved Sidsel Bohs begravelse havde han uanset brevet til Hans Japsen og uanset, at han ikke havde fået de krævede tre rigsdaler, holdt ligprædikenen. Han havde nogle uger senere modtaget, hvad familien ville give, men det var dog kun lidt efter omstændighederne. Om konflikten med Boel Hanskone og hendes to sønner Anders og Hans siger Wedel, at han havde sendt degnen til dem med en seddel med begæring om, at de deri skulle lægge deres offer, som han trods rykkere ikke havde kunnet få. Alle i sognet undtagen fire gårdmænd i Østerby havde bragt deres offer - som præsten ønskede det - indlagt i et stykke papir med deres navne påskrevet. "Men denne enke med hendes tilhængere har altid villet have noget frem for andre. Det er også lettelig at slutte, at hun og hendes sønner ere hovedmændene for begge disse klagemål, såsom det er hendes datter, Nan Jensen har fået, og som moderen i min sal. formands tid har signaliseret sig, at hun er blandt deres tal, som har deres lyst at trættes med en præst, så begynder i særdeleshed den ene søn Anders Hansen smukt med det samme, at han ikke skal synes at være vanslægtig. I den sted jeg nu vel havde haft årsag til at klage, så tager jeg dog med tålmodighed af kærlighed til fred mod al sådan fortræd, man endda ser og fornemmer, at disse få - såsom det er langt fra, at al menigheden derudi er interesseret - over alle deres forurettelser lægger dette dertil, at de og (anklager) mig for min gunstige øvrighed, såsom den da med nye oplæg og udsugen skulle forurolige dem, men Gud ved bedst alting, enten jeg har givet dem årsag at klage 
over mig eller de have givet mig årsag til at sukke over dem«. Han indstillede sagen til biskoppens afgørelse, wog hvor der kunne være nogen menneskelig skrøbelighed, som vel er muligt, der beder jeg efter strengeste ret ikke at forfares, at ikke embedets ære skulle formindskes og de opsætsige i deres ondskab desmere bestyrkes, helst eftersom her hverken kan klages over embedets forsømmelse eller vildfarende lærdom eller forargeligt levned. Jeg har den fortrolige tillid til Deres Højærværdighed, at De med Deres biskoppelige myndigheds interposition bringer disse få urolige til at bevise mig, deres sjælesørger, i de ting, som angår deres børns salighed, den skyldige lydighed, hvorimod jeg forpligter mig således herefter at omgås med dennem, at til klagemål ikke skal gives dennem ringeste årsag eller anledning «. Man fornemmer tydeligt $\mathrm{i}$ slutningen af brevet, at Andreas Wedel er ved at få en anelse eller mistanke om, at hans sag ikke stod helt så godt hos biskoppen, som han kunne have ønsket sig.

\section{Provstens indberetning 12. maj 1708}

Provst Junghans havde måske også lidt svært ved at få sin indberetning til biskoppen udarbejdet. Først den 12. maj og efter, som nævnt, at være blevet rykket gennem det grevelige herskab kunne han bekvemme sig til at fremsende den. Provsten meddeler heri, at han i kirken med udgang i evangeliet først havde talt om læreres og tilhøreres pligter mod hinanden og havde oplæst, hvad biskoppen havde anmodet ham om at efterforske. Han havde derefter henvendt sig til hver af mændene og havde spurgt, om de var bekendt med klagepunkterne, idet disse var indgivet $\mathrm{i}$ hele menighedens navn. Han fandt imidlertid, at mændenes udsagn ikke stemte overens. Efter at han dernæst havde ladet de unge træde ud fra kirkestolene, havde han bedt Andreas Wedel redegøre for, hvilken metode han anvendte ved de unges undervisning og overhøring. Han havde deraf ikke kunnet drage anden slutning, end at undervisningen var opbyggelig. "Men der det kom til det 4 . bud, da hørte jeg, at en person højt lo derad, da jeg forklarede de ord, de havde stødt sig på $\mathrm{i}$ deres angivende, således som jeg for Gud og alle retsindige vil forsvare. Imidlertid blev jeg nogle gange al min begæring uagtet overløben af en løs og ledig soldat, navnlig Mathies Hansen fornævnte person at antage nogle breve og løse sedler af hannem, som jeg bad hannem have tålmodighed med, indtil ungdommen var overhørt. Men som jeg det ikke kunne erholde, en stor del også løb af kirken, som jeg bad at 
blive til stede, men forgæves; fornævnte soldat endogså råbte mig hånligen til: Skal man også spørge præsten ad, når man vil gifte sig, hans broder truede mig, og jeg befrygtede stor uskikkelighed, beklagede jeg mig, at jeg ikke kunne gøre mit embede fyldest, men gå hellere ud af kirken, som jeg også gjorde. « Derefter var soldaten, som præsten fejlagtigt kalder Mathies i stedet for Anders, fulgt efter provsten over i præstegården, hvor han havde afleveret den skriftlige redegørelse og nogle "sedler«, hvis indhold provsten i forvejen var bekendt med. "Hvad som ellers fornævnte soldat om min tale og såkaldede råben spotteligen angiver, får jeg at lide, indtil så længe at hans ublu angivende $i$ en hel menigheds navn anderledes bliver bevist og han både for dette og det andet ved vor nådige høje herskabs ankomst kan vorde straffet.« Provsten undskylder, at indberetningen fremkommer forsinket - åbenbart med dårlig samvittighed efter grevens rykker - han havde været bortrejst og endvidere havde han formodet, at Andreas Wedel under et besøg hos moderen, der var præstekone i Brøns, havde aflagt en udførlig beretning til biskoppen - en lidt ejendommelig forklaring af provst Junghans, som i øvrigt sluttede sin indberetning således:

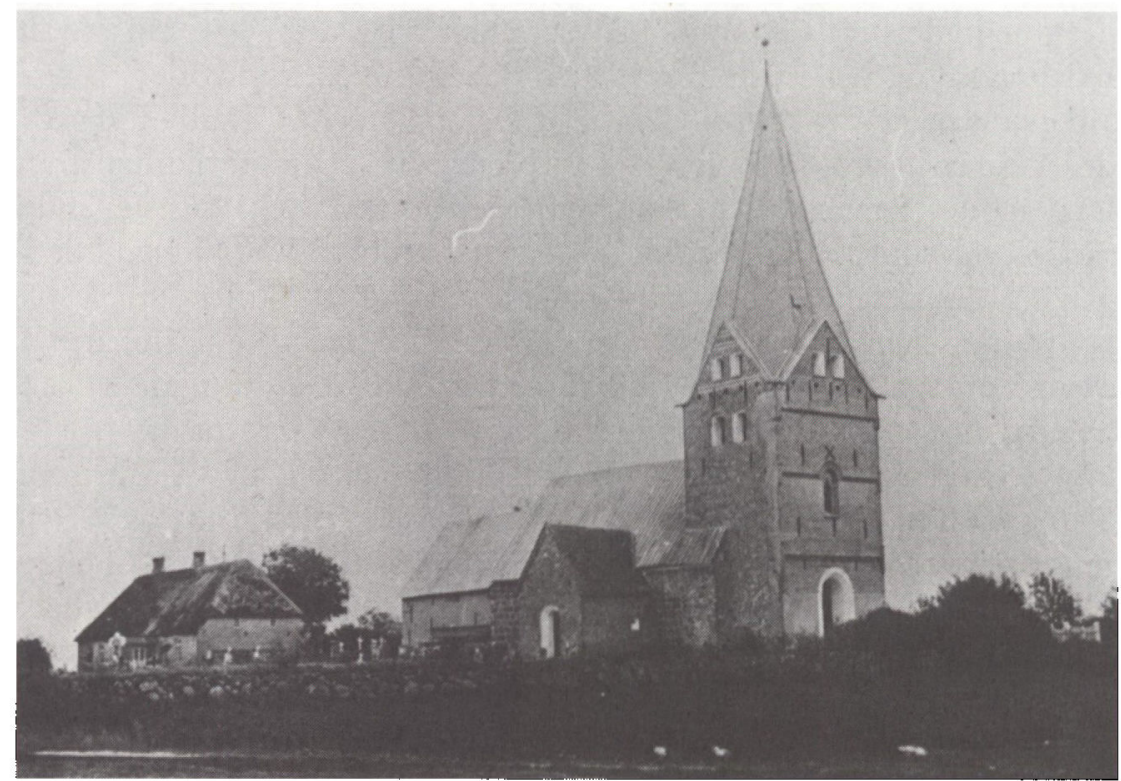

Daler kirke, set fra nordvest ca. 1920. Omkring kirkegården ses stendiget, der gennem arhundrederne har givet anledning til adskillige disputter; if. s. 20. T.v. i billedet ses den gamle skole. Fot. Johs. Timm, Tonder. Historiske Samlinger for Sonderjylland. 
»Imidlertid vil jeg ydmygst formode og ansøge, at jeg i mit embede må mainteneres (opretholdes, styrkes) og ikke slig en person tillades slige innormiteter at begå med hånlig angivelse efter største forurettelse, som ikke fortjener uden med høj straf andre til afsky at bevares.« Således så sagen altså ud med provstens øjne. Han havde helt stillet sig på Andreas Wedels side og benyttede sig endda af sit bekendtskab med overinspektør Eberhard Frostberg til at formå denne til for en nat at kaste Anders Hansen i tyvehullet på Schackenborg. ${ }^{9}$

\section{Landemode og birketing}

Det var jo en lidt anden fremstilling end den, Anders Hansen havde givet i sine to henvendelser til biskoppen af 8. marts og 8. april 1708; men denne har dog ikke været $i$ tvivl om sagens alvorlige sammenhæng. Efter at have opgivet tanken om at forelægge den for kongen, blev Andreas Wedel den 2. juni indstævnet af stiftsøvrigheden, der foruden biskoppen bestod af stiftamtmanden, som var identisk med lensgreve Hans Schack, til at give møde på et landemode, der skulle afholdes i Ribe den 20. juni 1708. Han skulle her svare på klagemålene og eventuelt lide straf - en mulighed, som han synes at have forudset $i$ sin redegørelse til biskoppen. Til landemodet stævnedes endvidere provst Junghans og en række medlemmer af Daler menighed. Imidlertid skete der det, at biskoppen blev syg og derfor ikke kunne administrere landemodet. Sagens behandling måtte derfor udskydes til næste landemode, som skulle afholdes i Varde den 24. oktober 1708. Vidneafhøringen og dokumentationen blev dog henvist til at skulle foregå ved Møgeltønder birketing, og Anders Hansen indstævnede derfor den 6. august provst, præst og i alt 30 vidner fra Daler sogn til tinge den 15 . august. Også birkedommer Christian Thomsen blev stævnet for at afgive forklaring på sin skrivelse om brudesmykket, og da Christian Thomsen desuden blev angivet at være besvogret med Andreas Wedel, måtte der indsættes en sættedommer. En anden af grevskabets dommere, nemlig Niels Saaby i Lustrup birk blev derfor af grev Schack beordret til at beklæde dommersædet - ganske vist under Christian Thomsens protest, idet han ikke vidste sig besvogret med præsten. Også provst Malthe Junghans protesterede, idet han nægtede at give møde på tinget med følgende skriftlige, noget nedladende begrundelse: "Eftersom jeg til i dag er af soldat Anders Hansen i Østerby på sine og consorters vegne til Møgeltønder birketing indstævnet for vidner at 
anhøre, så vidt mig skal vedkomme anlangende hvis forleden palmesøndag i Daler kirke skal være passeret, så er ikke min lejlighed for tinget at møde, men vil hermed aleneste rettens forvalter forestille lovens 1 . bogs 13 . kapitel 21. artikel, ${ }^{11}$ efter hvis anledning jeg vil formode, at bemeldte soldat ikke tilstedes nogen vidne, ord og tale angående efter så lang tids og så mange tingdages forløb at føre - med derhos tjenstlig begæring, at denne min lovmæssige protestation for retten må læses, påskrives og protokolleres.«

Der blev dog ikke taget hensyn til provstens protest; vidneafhøringerne fandt sted, uanset at der var gået adskillige tingdage siden palmesøndag, og dokumenterne blev fremlagt, behørigt påtegnet og indført $i$ tingbogen. Vidneafhøring og dokumentation varede $i$ to dage og sluttede med, at Andreas Wedel protesterede mod afhøringerne. En del af vidnerne var ikke uvildige, og han agtede at benægte, hvad der var blevet fremført, "agtede at denne forretning på behørig sted til svækkelse at indstævne, hvor han både sin protestations årsag og sin benægtelse ville forklare«. Han oplyser imidlertid ikke, til hvilken instans han vil appellere, og han nægtede $\mathrm{i}$ retten at navngive de vildige vidner og ville heller ikke lade protokollere, hvad han med god samvittighed edelig ville benægte. En afskrift af vidneafhøringerne og dokumenterne blev fremsendt til biskoppen, så at de kunne danne grundlaget for sagens behandling på næste landemode i Varde den 24. oktober 1708 .

\section{Forlig og landemode i Varde}

Da sagen blev forelagt her den nævnte dag, var klokken imidlertid blevet "halvgåensyv«, og forhandlingerne måtte derfor udsættes til næste morgen kl. 7. Parterne såvel som provsterne fik besked på at indfinde sig på dette tidspunkt. Da sagen så blev genoptaget, viste det sig, at bøndernes ordfører Anders Hansen var blevet syg og sengeliggende, og som stedfortræder for ham mødte derfor broderen Hans. Han havde ingen skriftlig fuldmagt, hverken fra broderen eller fra de øvrige involverede i klagemålet; men han var mundtligt af dem blevet anmodet om at repræsentere dem på landemodet, og $\mathrm{i}$ den anledning havde man overladt ham sagens dokumenter. Han blev derfor godkendt som menighedens advokat, og af det forholdsvis korte referat ses, at han fremlagde en stævning, som var blevet forkyndt for provst Malthe Junghans den 15. oktober 1708, samt et indlæg, som var skrevet 
af Anders Hansen og dateret den 20. oktober. Heri blev der redegiort for hele sagens forløb. Hvad der var vigtigst, var imidlertid, at Hans Hansen kunne fremlægge et forlig, der var skrevet på stemplet papir og dateret Daler præstegård den 17. oktober 1708. Dokumentet blev oplæst på landemodet, men er ikke gengivet i landemodeprotokollen. Der oplyses dog i denne, at det var underskrevet af Andreas Wedel, og at sognepræst i Emmerlev Marcus Kiel og sognepræst i Visby Jens Gregersen havde underskrevet som vitterlighedsvidner. Omvendt forelagde Andreas Wedel et ligelydende dokument, som var underskrevet af de klagende bønder Hans Boesen, Anders Hansen, Hans Rasmussen, Laurids Mattesen, Hans Boesen, Jørgen Nielsen og til vitterlighed af delefoged i Møgeltønder birk Paul Pletz og delefoged i Emmerlev distrikt, kirkeværgen i Daler Niels Brink. Der er åbenbart både fra gejstlig og verdslig side lagt pres på præst og bønder for at få et forlig i stand. Det, som i og for sig er mest iøjnefaldende ved forligsforhandlingerne, er nok, at provst Junghans ikke nævnes i denne forbindelse, og at to af grevskabets delefogeder medvirkede. Grev Schack har nok på trods af en mere eller mindre modvillig overinspektør søgt at få denne ubehagelige sag ud af verden.

Efter at de to ligelydende forligsdokumenter var blevet læst og påtegnet $\mathrm{i}$ landemodet, anmodede Andreas Wedel om, at det måtte blive noteret $i$ protokollen, at "det var hans ydmygste begæring, at anførte forlig af Hans Højgrevelige Excelence og Hans Højærværdighed biskoppen måtte vorde konfirmeret og den begangne forseelse højgunstigst efterladt«. Vi kender som sagt ikke ordlyden af forliget, men denne sidste udtalelse af Anders Wedel tyder jo stærkt på, at han har måttet krybe til korset og bøje sig for sine sognebørn. I øvrigt havde han ikke mere at fremlægge og sige på landemodet, og Hans Hansen havde heller ikke mere at fremlægge i sagen, men han understregede dog, at han "reserverede« sig til forliget og de øvrige i retten rette fremlagte dokumenter.

Provst Malthe Junghans var jo også indstævnet til landemodet, men han gav ikke møde. I stedet mødte på hans vegne byskriver $\mathrm{i}$ Varde Søren Hvid, som fremlagde et indlæg fra provsten, dateret den 20. oktober 1708. Hvad dette indlæg gik ud på, fremgår ikke af landemodeprotokollen; men det ser ud til, at provsten også har måttet stå til regnskab for sin embedsførelse i forbindelse med Daler-præstens strid med sin menighed. Sagen behandledes hele formiddagen af de lærde provster og kunne først sluttes henad kl. 13 med afsigelse af en kendelse af følgende ordlyd: "Såsom sagen befindes af den beskaffenhed, at 
parterne har indbyrdes forligt sig, bør dog sognepræsten udi Daler, hr. Anders Wedels brøst og forseelse endelig påkendes, og som provsten mag. Malthe Junghans selv er stævnet, så vil derfor samme sag af en anden provst, som biskoppen dertil anordner, videre påtales og til førstkommende Riber landemode til påkendelse indstævnes efter lovens 2 . bogs 16 . kapitels 5 . artikel, ${ }^{12}$ som og bemeldte provst, mag. Malthe Junghans udi sit indlæg påstår, at citantens og hans consorters prætentioner imod hannem bør først for underretten at udføres. Og som han selv er provst i Møgeltønder herred, udi hvilket hans kald ligger, så beskikkes til provsteretten udi denne sag efter foregående stævnemål så som vice-præpositus lovligen og forsvarligen at administrere sognepræsten udi Emmerlev hr. Marcus Kiel og til at sidde retten med ham 2'de præster udaf Lø herred, nemlig hr. Nissenius Weddel, sognepræst til Døstrup og hr. Peder Martensen Stavning, sognepræst til Medolden i henseende til, at der foruden de indstævnede er ej flere præster udi forskrevne Møgeltønder herred end bemeldte hr. Marcus Kiel. $^{13}$

Sagen blev altså henvist til en provsteret, men hvornår denne blev holdt, og hvad dens kendelse gik ud på, ses ikke, da provsteretsprotokollen er gået tabt. Helt sikkert er det imidlertid, at provst Malthe Junghans har følt sig overordentligt ilde til pas ved, at hans embedsførelse var blevet taget op til undersøgelse og i det hele taget ved den vending den ulyksalige Daler-sag havde taget. Han havde bakket Andreas Wedel op, og nu så han også sig selv anklaget for dårlig embedsførelse, og at han stod svagt, dels over for biskop Muus, hvem han havde haft flere disput'er med og dels over for sine provstekolleger ved landemodet i Varde. Det var gået den lærde, orientalske filologs ære for nær, at han har skullet finde sig $i$ at blive sat på plads af nogle simple bønder og en gemen soldat. Det gik ud over hans helbred. Der siges, at han gik sund og rask i seng den 15 . november 1708 og blev fundet død i sengen den følgende morgen ${ }^{14}$ ramt af et hjerteslag.

\section{Forligets misligholdelse og ny landemodedom}

Under provsteembedets vakance blev det da provsten i Lø herred, sognepræst i Ballum Peder Brorson og mærkværdigvis ikke den ovenomtalte viceprovst Marcus Kiel, som den 30 . maj 1709 måtte indstævne Andreas Wedel til landemodet i Ribe domkirke den 19. juni. Andreas Wedel skulle nu lide dom for den brist og forseelse, som han af 
nogle medlemmer af sin menighed var blevet overbevist om på sidste landemode i Varde. Det var provst Brorson, som var anklager eller i hvert fald den, som forelagde sagen og dens dokumenter for landemodet. Fra Andreas Wedel forelå et skriftligt indlæg og endvidere fremtrådte Anders Hansen uden stævnemål for landemodet med en beklagelse over, at Andreas Wedel ikke i et og alt havde villet overholde det på Varde landemode stadfæstede forlig. Anders Hansen begærede, at Andreas Wedel måtte få tilhold om at overholde forliget $i$ alle dets punkter. Sagen kunne ikke færdigbehandles den 19. juni, og provsterne måtte derfor indfinde sig igen $\mathrm{i}$ domkirken den følgende dag kl. 9 formiddag. Efter at landemodet igen var sat, blev der afsagt følgende kendelse i sagen: "Såsom sognepræsten udi Daler, hr. Anders Wedel udi sit indlæg af d. 19. juni 1709 deprecerer og afbeder den brøst og de forseelser, som hannem ere overbeviste og lover herefter nøjere og bedre at observere og rette sig efter kongens lov og kirkeritual, og som samtlige provster giver hannem ellers for sit øvrige forhold $\mathrm{i}$ embede og levnet et godt vidnesbyrd, bedendes med hannem, at han som en ung mand, der ikke længe haver været udi embedet, ikke til velfærds spilde, men med mulkt må blive straffet; siden og sagen imellem hannem og hans tilhørere allerede forhen er bleven forligt, da efter sådan beskaffenhed bliver hans fortjente straf for denne gang således modereret, at han skal betale til fattige præsteenker 30 rigsdaler og udi sagens omkostninger til provsten, hr. Peder Brodersen 4 rigsdaler og erlægge samme penge, nemlig de 30 rigsdaler udi tvende terminer, halvdelen udi førstkommende Varde landemode 1710 og de 4 rigsdaler til bemeldte provst inden 6 uger herefter under udsøgning efter loven. Og bliver han, hr. Anders Wedel alvorligen advaret og formanet, at han, så kær som han haver sin velfærd, troligen holder det løfte, som han udi foranførte indlæg gjort haver, så at han under sit embedes forbrydelse herefter ikke understår sig enten ved katekisationen eller nogen anden præstelig forretning at indføre eller bruge nogen novitet (nyhed) eller sådan skik, som enten er imod loven og ritualet eller og ikke finder grund derudi, ej heller imod loven at foreskrive nogen, hvad hannem for præstelige forretninger skal gives, men såvel uden al undskyldning, prætekst og kontravention rette sig efter højstbemeldte Kongl. Majestæts lov og ritual og bliver ved kirkernes udi disse riger derpå grundede skik og brug, som uden gerrighed og egennyttighed, egensindighed og fortrædelighed, med den fornøjelighed, sagtmodighed, beredvillighed, fordragelighed og kærlighed, som bør være hos en Guds ords tjener, forholder sig efter embeds- og edspligt $i$ alle måder uden forringelse 
vel og upåklagelig, så at hans lærdom og levnet svarer hinanden til såvel embedets ære som menighedens opbyggelse og gode eksempel, således som hans kalds værdighed udkræver, hvilket alt sammen såvel som ubrødeligen at holde den imellem hannem og hans tilhørere gjorte forlig udi alle dets punkter, han her for retten ydermere bør at love og med sit navns underskrift herudi protokollen forsikre. Andreas Wedel mp. $^{15}$

Det må have været med overordentligt tungt hjerte, at Anders Wedel har underskrevet protokollatet. Det var jo for ham en meget ydmygende kendelse, og der var et stort spring mellem denne og de breve, han ind under jul 1707 havde sendt til sine sognebørn. Med den efter tidens forhold overordentlig store bod blev den pengeglade præst også ramt på et ømt sted. Anders og Hans Hansens taktik med i deres anklage at lægge hovedvægten på Wedels indførelse af konfirmationen og hægte hans opkrævninger af offer og accidenser på denne anklage viste sig altså at være et klogt psykologisk træk, for landemodets velærværdige provster har sikkert godt kunnet forstå, at en ung præst har ønsket at sætte sin indtjening i vejret; men en egenmægtigt indførelse af et nyt ritual kunne man ikke acceptere, når Danske Lovs bestemmelser skulle overholdes, og det skulle de.

\section{Andreas Wedels senere virke}

Der siges, at Andreas Wedel senere kom på en bedre fod med sin menighed, men det må i hvert fald have varet nogle år. Han var således aktiv ved opførelsen af et pulpitur i kirken, hvilket menigheden i høj grad var utilfreds med, idet man til finansieringen heraf uretmæssigt forhøjede kirketienden. Denne strid, hvori det grevelige herskab som kirkens patronat var den egentlige anklagede førtes over birketing frem til højesteret $\mathrm{i}$ årene 1713-17 af Anders og Hans Hansen og endte med en sejr for tiendeyderne. Pulpituret stod $i$ hvert fald $i$ de år sagen verserede, tilspigret, og hvornår det er blevet taget i brug, er ikke helt klart. ${ }^{16}$ I denne sag synes Andreas Wedel ikke at have været direkte indblandet. Han har imidlertid nok støttet sin patron - i hvert fald har han ikke været på tiendeydernes side. Selv havde han 1716-17 nogle stridigheder med bønderne om præstetiende af den havre, som de såede i kogsjorden, og som de angav lå under spadelandsretten. En klage til det grevelige herskab nyttede kun lidt, idet Andreas Wedel herfra blev henvist til at indklage bønderne for birketinget. Dette ville han dog 
ikke, da »hans pung ikke ... vejer dertil at have med så mange at gøre, blandt hvilke de fleste er rige og formuende $\ll .{ }^{17}$

Uanset den skarpe irettesættelse, han modtog på landemodet $\mathrm{i}$ Ribe 1709 i forbindelse med den ydmygende afbigt og trods sin ungdom blev Andreas Wedel ikke desto mindre 1712 udnævnt til provst i Møgeltønder herred, som omfattede de tre sogne Møgeltønder, Emmerlev og Daler. Det er vel et nådigt herskab, som har gjort sin indflydelse gældende. Eftertidens ret positive dom over ham skyldes nok, at han så tidligt sluttede sig til den pietistiske bevægelse, og at han nidkært arbejdede for dens fremme. ${ }^{18}$ Som provst tålte han ikke slinger m.h.t. den rette tro, og man kan derfor også i bispearkivet finde en indberetning fra ham 1717, hvori han anmelder sin ikke-pietistiske kollega i Møgeltønder sogn Johan Henningsen for at lade overtro gå i svang $\mathrm{i}$ forbindelse med bekæmpelsen af den da grasserende kvægsyge. ${ }^{19}$

I øvrigt beslaglagde penge og økonomi også fremover meget af hans tid og tanker. Som indledningsvis omtalt sluttede han ved sit embedes tiltrædelse en kontrakt med svigerfaderen om de økonomiske betingelser i forbindelse hermed. Efter svigerfaderens død opstod der imidlertid stridigheder med svigermoderen, som dog 1707 til en vis grad var blevet udglattet ved et forlig, hvorved der blev gennemført en mindre ændring af kontrakten, men heller ikke dette forlig holdt. Allerede 1713 måtte biskop Ocksen igen forlige de to parter, og 1720 kom stridighederne om overholdelsen af kontrakten for en provsteret i Møgeltønder. Her dømtes Andreas Wedel til foruden sagsomkostningerne at skulle betale svigermoderens 1530 rigsdaler, en uhyre sum, som man skulle tro, at det måtte være helt umuligt for en præst i et så lille sogn som Daler at præstere. Svigermoderens sagfører under provsteretssagen var en anden svigersøn, rådmand Peter Giese i Tønder. Det har sikkert været ret så hyggelige familiesammenkomster i den familie, men man hører efter 1720 dog ikke om flere stridigheder inden for den. Måske har erfaringen og alderen også lært Andreas Wedel, at det ikke altid lønnede sig at sætte en formodet ret på spidsen. Han havde 10 år at slikke sine sår $i$, inden han døde 1730.

\section{NOTER OG HENVISNINGER}

Citaterne i artiklen er gengivet i en noget moderniseret retskrivning, idet ordstilling og visse gamle bøjningsformer dog er bibeholdt.

1. Se Sønderjyske Årbøger 1937, s. 273-76. 
2. Daler kirkebog.

3. Biografiske oplysninger om Andreas Wedel findes i Arends: Gejstligheden i Slesvig og Holsten II s. 351 (med kildehenvisninger), i Kirke og Sogn i Fortid og Nutid, red. Niels Munk Plum og G. Sparring Petersen, heri Daler sogn ved H. Birkegaard, i Paul Nedergaard: En dansk Præste- og Sognehistorie, særudg. Sønderjylland I, s. 303 og Carsten Petersen: Slesvigske Præster, s. 105. Se endv. Daler præstearkiv Ad 1 Liber daticus 1766-1827.

3a. Schackenborg godsarkiv. 1690-1746 (49). Breve, resolutioner ... .

4. Dokumenterne i sagen er $\mathrm{i}$ artiklen gengivet efter Møgeltønder birks tingprotokol 1706-11 i landsarkivet i Åbenrå, samt efter pakke I 36 i arkivet på Schackenborg.

5. En forordning om skudsmål blev skarpet 1701 .

6. Boghvede.

7. Plattysk betegnelse for en lille mønt; i begyndelsen af 1700-årene almindeligvis 3 sk.

8. Der er to gårdmænd, som hedder Hans Boesen i Daler sogn.

9. Oplyst i den såkaldte lagieproces, hvis protokoller og papirer beror i Schackenborg godsarkiv på landsarkivet.

10. Denne karakteristik af Boel Hanskone er ikke ueffen. Den svarer helt til det indtryk, man får af hende som inspirator og støtte for de to sønner under lagieprocessen mod det grevelige herskab.

11. "Hvo vidne vil føre på, hvis een anden sagt haver, han skal det gøre på fersk fod og til første ting, som han lovlig kald og varsel til kan give, efter at han om sådan påsagn er videndes vorden; ellers skulle vidne på eens mund ikke galde imod hans benægtelse«.

12. «Dersom de (provsterne) befinde nogen brøst eller forsømmelse hos præsterne eller andre deres underhavende gejstlige i deres embede, forhold og levnet, da skulle de flittelig påminde dem, hvad de bør at gøre, og hvilke sig da ikke ville rette, dennem skulle de indføre for superintendenten, og hvilke han da ikke kan sætte til rette, dennem skulle de stævne til provstemode for kongens stiftsbefalingsmand og superintendenten og aldeles intet uskikkeligt dølge eller underslå, men tilbørligen lade det påtale og straffe, så fremt de ikke selv derfor vil stande til retteর.

13. Ribe stifts landemodeprotokol, 1690-1711, fol. 156f i Ribe bispearkiv i Viborg landsarkiv.

14. Møgeltønder præstearkiv Ba 1 1765-1872 Liber daticus i landsarkivet. Jfr. Paul Nedergaard: Anf. arb. I s. 309.

15. Ribe stifts landemodeprotokol, 1694-1711, fol. 164ff.

16. Findes oplyst i den tidligere nævnte lagieproces.

17. Ribe bispearkiv. Møgeltønder hrd. 1583-1778, 1717 13/5, landsarkivet Åb.

18. Jfr. Daler præstearkiv Ad 1 1766-1827. Liber daticus, landsarkivet.

19. Samlinger til jysk Historie og Topograf, 4. rk., III, s. 220-23. Årstallet her fejlagtigt angivet som 1713. 
